\title{
Bigger, faster, stronger! an overview of anabolic androgenic steroids and their use and impact on the sport industry
}

\begin{abstract}
The use of anabolic androgenic steroids (AAS) in sport is no longer confined to the power disciplines and has become a wide-spread issue throughout the general population. AAS are synthetic versions of the male hormone testosterone and display both anabolic and androgenic properties. It is the anabolic properties that are responsible for the muscle binding characteristics and are the main attraction for users. The primary purpose of this review was to provide an overview of the use of AAS in the sports industry by outlining the history of AAS use, the role of AAS in the Olympic success of Soviet athletes and the German Democratic Republic. Furthermore, case studies of the high profile cases of Ben Johnson, Marion Jones and Lance Armstrong were also examined along with the consequences of their drug use. Also outlined are the reasons for AAS use, the variety of ways in which they are used and short and long-term adverse side effects associated with their use. This research has highlighted problems with previous AAS literature as there is a lack of research into the long-term side effects of AAS use.
\end{abstract}

Keywords: anabolic androgenic steroids, AAS, adverse effects, athletes, doping, performance enhancing, Ben Johnson, Marion jones, lance Armstrong
Volume I Issue 3 - 2015

\author{
Andrew O’Hagan, Holly Walton \\ School of Science and technology, Nottingham Trent University, \\ UK
}

\author{
Correspondence: Andrew O'Hagan, Nottingham Trent \\ University, Nottingham, UK, Tel 44I I5-8483 I53, \\ Email andrew.ohagen@ntu.ac.uk
}

Received: October 08, 2015 | Published: November 09, 2015
Abbreviations: AAS, Anabolic Androgenic Steroids; PED, Performance Enhancing Drugs; GDR, German Democratic Republic; USADA, US Anti-Doping Agency; BLACO, Bay Area Laboratory Co-operative; IOC, International Olympic Committee; MDA, Misuse of Drugs Act

\section{Introduction}

Since their first appearance on the sporting scene in the $1950 \mathrm{~s},{ }^{1,2}$ Anabolic Androgenic Steroids (AAS) have often been the performance enhancing drug of choice for athletes in a variety of disciplines and remain one of the most controversial topics in sport today. AAS are synthetic derivatives of the male sex hormone testosterone and display both anabolic and androgenic effects upon the body. Anabolic effects refer to the tissue binding effect of these hormones while androgenic refers to the development of masculine characteristics. ${ }^{1}$ The androgenic effects of the hormones are more evident in female and adolescent users and are undesirable. As a result of this, many attempts have been made to synthesis a steroid that has purely anabolic effects but this has not been achieved to date. ${ }^{3,4}$ AAS abuse is a widespread problem that is not confined to professional athletes, for example, they are also used by bodybuilders, college students and non-competing amateurs. ${ }^{2}$ It is the anabolic effects of AAS that make them desirable to athletes, allowing them to add bulk and increase muscle mass to give them that 'edge' other fellow competitors. But this 'edge' comes at a price and there are many adverse side effects to the use of AAS, some of which are dependent upon the dose and range from temporary effects such as acne and increased aggressiveness to permanent effects such as the deepening of the voice in women and the development of breasts in males (gynecomastia). ${ }^{3}$ The objective of this review is to provide an insight into the usage of AAS in the sport industry. It will consider what steroids are, the reasons for use, how they are used along with the physiological and psychological effects of their use. Additionally, it will look at the law regarding the use of AAS along with case studies of high profile users such as Lance Armstrong, Ben Johnson and Marion Jones. The limitation of this review is its reliance upon previously published literature and data. In the case of data provided on the extent of AAS usage, this is expected to be lower than the actual value. This is a result of difficulty in the studies used for this review in determining the exact extent to which AAS are used as people are reluctant to admit usage. ${ }^{5}$

\section{Discussion}

\section{What are steroids?}

The term "steroid" is often misunderstood, particularly in society today. To many, the word "steroid" refers to the drugs that are abused by athletes to improve their performance, which is probably a result of the prevalence of AAS.

According to the National Institute of General Medical Sciences, steroid is the chemical name given to a substance "...that has a characteristic chemical structure consisting of multiple rings of connected atoms". ${ }^{6}$ The basic chemical structure of which can be seen in Figure 1.?

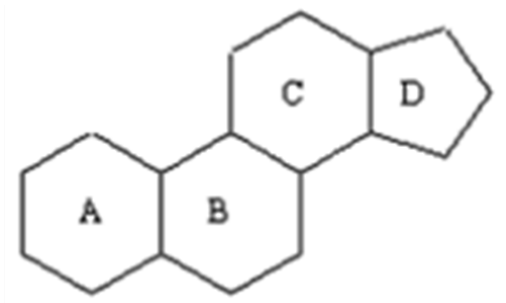

Figure I Basic chemical structure of a steroid. ${ }^{7,43}$

By definition, this classes vitamin $\mathrm{D}$, cholesterol and oestrogen as steroids, along with the better known testosterone, all of which are 
produced naturally by the body. ${ }^{6}$ Many synthetic forms of steroids have been produced and are used in medicine worldwide. The two main types are corticosteroids and AAS and the two should not be confused. Corticosteroids are synthetic versions of hormones produced naturally in the adrenal grands and are anti-inflamitaries. They are used to treat medical conditions such as asthma and arthuritus and have no muscle building ability. ${ }^{8}$ AAS, on the other hand, are synthetic derivatives of the male sex hormone testosterone ${ }^{1}$ and have limited medicinal use. They are used mainly to treat anemia, muscular dystrophy and can also be used as part of a replacement therapy, usually for older men who have lost the ability to produce their own testosterone. In these cases, AAS are prescribed in a physiological dose (approximately $50-75 \mathrm{mg}$ a week). ${ }^{9}$ The way in which AAS work is similar for all steroids at a cellular level. As AAS are fat-soluble, they are able to diffuse across the cell membrane into the cytoplasm of a cell. ${ }^{7}$ Here they bind to a steroid receptor and are carried into the nucleus of a cell where they bind to the DNA and promote the transcription of messenger RNA (mRNA). This results in an increase in protein synthesis, Figure 2 the effects of which are dependent on the type of cells the AAS has bound to. For example, in muscle cells, the size of the muscle will increase and in bone cells, the size of the bone will increase. ${ }^{10}$ When an athlete trains intensely, for unknown reasons, the testosterone levels in the body drop dramatically. Along with this, the body produces a hormone called glucocorticoid which reduces inflammation but is also catabolic, meaning that it breaks down muscle tissue. It is believed that, when taken in doses exceeding the physiological dose, AAS effect the hormone levels in the body by not only increasing the levels of testosterone but also by decreasing the levels of glucocorticoid. This results in accelerated muscle repair along with the blockage of muscle wasting effects of glucocorticoid allowing the muscles to become bigger and stronger. ${ }^{9}$

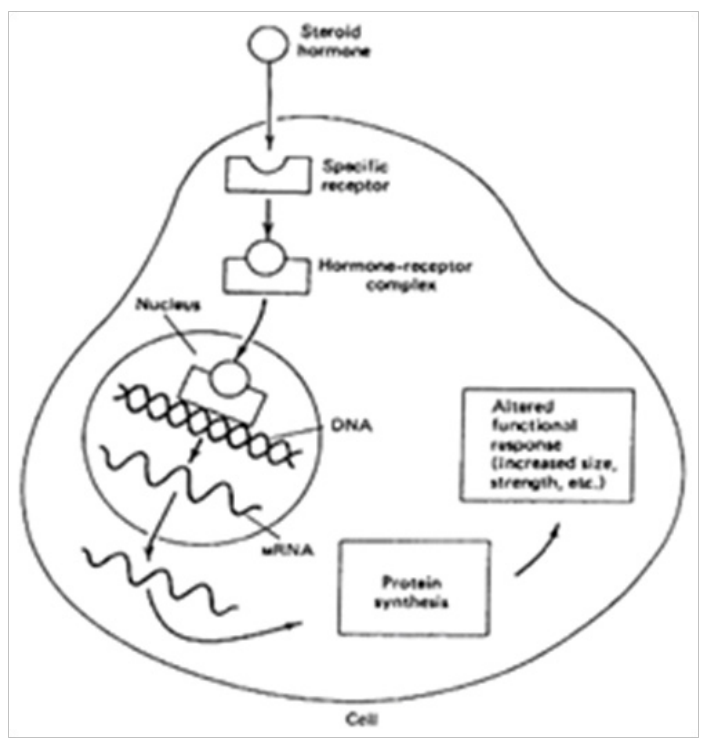

Figure 2 Mechanism of AAS action. ${ }^{7,43}$

\section{Types of steroids}

As mentioned previously, AAS are synthetic derivatives of the male sex hormone testosterone ${ }^{1}$ and are classified according to their route of administration, either orally or by injection. It should be noted here that injectable AAS are always injected intramuscularly and never intravenously as this could result in the development of an oil embolism, which can prove fatal, along with large variations in the levels of AAS present in the body. ${ }^{11}$ The most effective route of administration of an AAS is determined predominantly by the way in which the testosterone molecule has been modified. Figure 3 shows the nomenclature of a testosterone molecule, $\alpha$ and $\beta$ denote the locations of the two most common modifications at carbon $17 .{ }^{12}$ Figure 3 Adaption of figure in Taylor $^{13}$ showing "nomenclature of the testosterone molecule. The numbers refer to carbon atoms. $\beta$ and $\alpha$ refer to the stereochemistry of the hydroxyl and hydrogen groups at carbon 17 ". ${ }^{12}$ When administered orally, unmodified testosterone molecules are rapidly degraded by the liver in a process known as first pass metabolism. Modification to the testosterone molecule at the 17- $\alpha$ position, commonly with the addition of a methyl or ethyl group, makes the molecule more resistant to this process and allows an effective dose to be maintained. Oral AAS are the starting point for many users and are popular for their convenience of use.

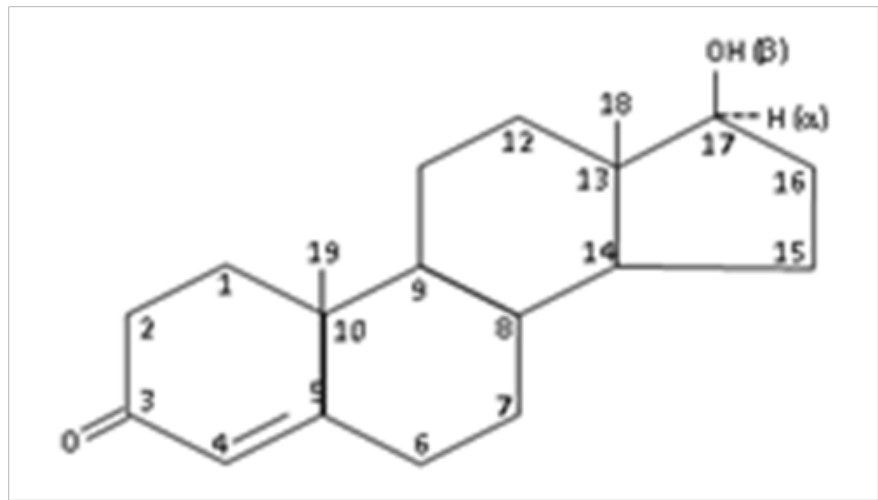

Figure 3 Adaption of figure in Taylor" showing "nomenclature of the testosterone molecule. The numbers refer to carbon atoms. $\beta$ and $\alpha$ refer to the stereochemistry of the hydroxyl and hydrogen groups at carbon 17". ${ }^{2,13}$

However, as the full dose of the oral AAS passes directly to liver, frequent use can result in liver toxicity which is why they are often used in cycles as will be discussed later in this review. ${ }^{12,14}$ After a few months of using oral AAS, many users progress onto injectable AAS. These steroids are modified at the $17-\beta$ position with the most common modification being the addition of an ester side chain. As these steroids do not have the modification at the 17- $\alpha$ position they are ineffective if taken orally and will not be able to resist the degradation by the liver. ${ }^{12}$ This modification allows the AAS to absorb into fat deposits in the body, making them more stable and resulting in a slower administration but more effective action of the drug than those administered orally. ${ }^{3}$ Examples of commonly abused AAS that are prepared for both oral and injection can be seen in Table $1 .^{15,16}$

Table I Examples of commonly abused oral and injectable AAS. Steroids are listed in the form of: generic name (common trade name). ${ }^{11,15,16,33}$

\begin{tabular}{ll}
\hline Oral steroids & Injectable steroids \\
\hline Methandrostenolone (Dianabol*) & Boldenone Undecenoate (Equipoise) \\
Oxandrolone (Anavar*) & Nandrolone Decanoate (Deca) \\
Oxymetholone (Anadrol*) & Sustanon (Sostenon) \\
Testosterone Undecanoate (Andriol) & Testosterone Enanthate (Testoviron) \\
Methenolone Acetate (Primobolan*) & $\begin{array}{l}\text { Testosterone Cypionate (Testex } \\
\text { Leo) }\end{array}$ \\
Stanozolol (Winstrol*) & Stanozolol (Winstrol Depot) \\
$*$ I7- $\alpha$ - Alkylated & \\
\hline
\end{tabular}


Oral steroids have an effect upon the body much more quickly than their injectable counterparts, however the active duration is much shorter as a result of their short half-lives and so the drug has to be taken on a more regular bases. ${ }^{17-19}$ The half-life of a drug is defined as:"...the amount of time during which the blood level of it [the drug] is reduced to one-half of its original blood concentration". ${ }^{12}$ The short half-lives of oral steroids results in the detection time of the steroid being relatively short. In contrast, injectable steroids have a much greater half-life than oral steroids as the drug is stored in the fat deposits in the body. This makes them more stable than oral steroids and easier to maintain but this consequently means that their detection times are much greater. ${ }^{3}$ The difference in the half-lives and detection times of oral and injectable steroids is highlighted in Table 2. ${ }^{17}$

Table 2 Examples of the difference in half-lives and detection times of both oral and injectable steroids. ${ }^{2,4}$

\begin{tabular}{llllll}
\hline Oral steroids & \multicolumn{5}{c}{ Injectable steroids } \\
\hline Steroid & Half-life & Detection time & Steroid & Half-life & Detection time \\
\hline Dianabol & 8 hours & 6 weeks & Equipoise & 15 days & 5 months \\
Anavar & 12 hours & 3 weeks & Deca & 15 days & 18 months \\
Anadrol & $<16$ hours & 8 weeks & Sustanon & 18 days & $3-4$ months \\
Andriol & $<12$ hours & 5 weeks & Testosterone Enanthate & 10.5 days & 3 months \\
Primobolan & 6 hours & 5 weeks & Testosterone Cypionate & 12 days & 3 months \\
Winstrol & 8 hours & 3 weeks & Winstrol Depot & 24hours & 9 weeks \\
\hline
\end{tabular}

\section{Reasons for use}

The focus of this review is the use of AAS in the sport industry however this does not mean that AAS are restricted to the sport industry. Users of AAS can be separated into three categories; sports competitors, occupation users such as security guards and "body image users" each with their own, slightly different reasons for using AAS. ${ }^{4}$ Sport competitors primarily use AAS to gain a competitive edge over their opponents by increasing their strength and power. ${ }^{3}$ AAS have proven time and time again how effective they are at providing this edge, the extent of which is illustrated by the statement of Harrison Pope, Professor of Psychiatry at Harvard Medical School, below:

"Steroids are incredibly effective. A young guy who eats badly, sleeps badly, smokes, drinks too much alcohol, misses half of his gym workouts and takes steroids can blow away the most dedicated, most gifted athlete who does not take steroids in terms of sheer muscle gain". ${ }^{8}$ For the majority of sports competitors, the window of opportunity is small which can introduce a financial aspect to the motivations for AAS use. This motivation to use AAS over natural methods is understood by sport physiologist David Sandler of Strength Pro Inc. who has witnessed first-hand the pressure that is placed on young athletes to perform when they are faced with signing a contract for $\$ 50$ million. ${ }^{9}$ It is at this point when "... when some athletes turn to anabolic steroids for an extra edge, to beat the clock and cash in on success". ${ }^{9}$ A sports competitor's decision to use AAS will not be taken as lightly as the same decision would be by an occupational user or "body image user". This is due mainly to the presence of the World Anti-Doping Agency (WADA) and their associated anti-doping policies which serve as a deterrent for many athletes. The World Anti-Doping Code a document that harmonises anti-doping policies in a variety of sports bodies worldwide, including the Olympic movement, and abides by five International Standards to ensure consistency. These five International Standards are: testing, laboratories, Therapeutic Use Exemptions, the List of Prohibited Substances and Methods, and the protection of privacy and personal information. ${ }^{20}$ As the ways in which sports competitors can abuse substances and methods to enhance their physical performance have advanced over the years, The Code has been amended accordingly with the most recent revision being introduced on 1st January $2015 .^{20}$
However, some athletes still make the decision to use AAS despite the presence of WADA and The Code and are willing to take the risk of getting caught. In comparison, this decision may be taken more lightly by occupational users and "body image users" who's main motivation for using steroids is the desire for a certain physique. " "Body image users" in particular have the desire to look muscular and "ripped" and the numerous " 8 week transformation" images Figure 4 that are displayed on AAS retail websites further enhance this desire. ${ }^{21}$

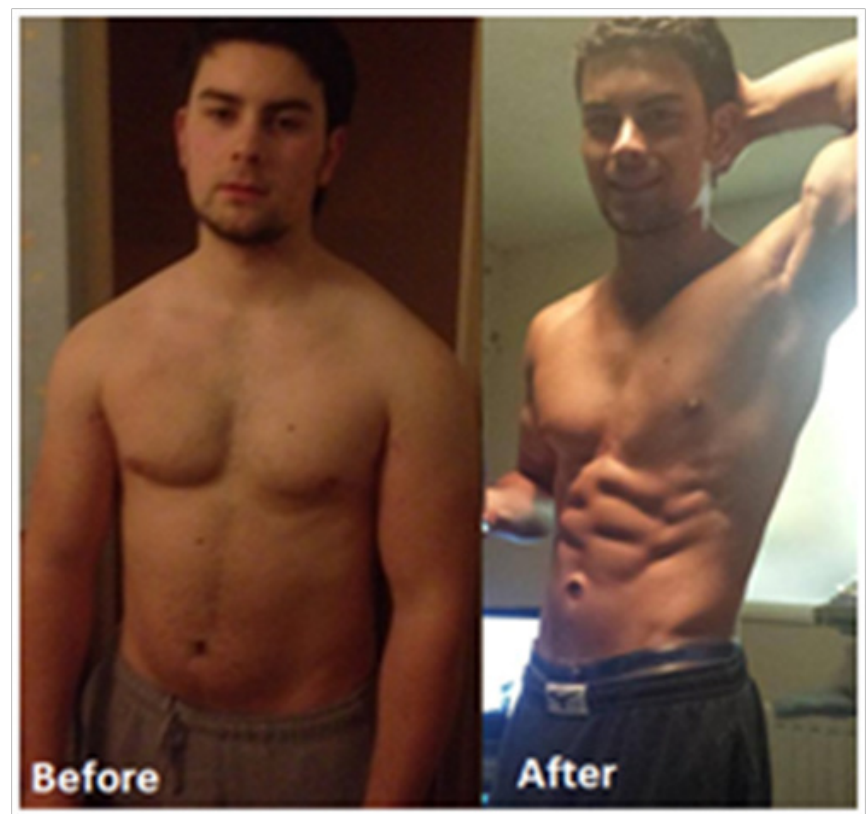

Figure 4 Example of an "8 week transformation" promoted by AAS retail websites. ${ }^{6,21}$

\section{How are steroids used?}

Although the use of AAS can greatly boost the performance of an athlete, they are not a form of "magic potion" and their use on their own is limited. In order to gain optimal results from AAS their use must be combined with a carefully planned and managed diet, exercise 
program and appropriate rest periods. ${ }^{11}$ AAS are often administered in high doses which have been known to be up to 100 times greater than the physiological dose. ${ }^{2}$ In order to obtain the quantities of AAS needed to administer these doses, AAS that are intended for veterinary use are commonly used. An example of this is Equipoise which is obtainable in 50 or $100 \mathrm{~mm}$ vials as oppose to the regular quantities of $1,2,5$ or $10 \mathrm{~mm}$ vials. Winstrol-V is another example of an AAS intended for use by veterinarians use large animals such as horses and cattle. With a concentration of $50 \mathrm{mg} / \mathrm{cc}$, Winstrol-V has a significantly higher concentration than that intended for human consumption. ${ }^{12}$ As discussed in the previous chapter, AAS come in two forms, oral and injectable and it is not uncommon for athletes to use a combination of the two. Oral steroids are simply swallowed whereas the injectable steroids are injected intramuscularly. The three main sits that are suitable for intramuscular injection are the gluteus maximus, quadriceps and the triceps. Some injectable steroid users believe that spot-site injections result in more localised muscle growth, however, the risk of injecting spot-sites increase as the muscle groups become smaller and closer to nerves and veins. ${ }^{11}$ The locations of these spot-sites can be seen in Figure 5.

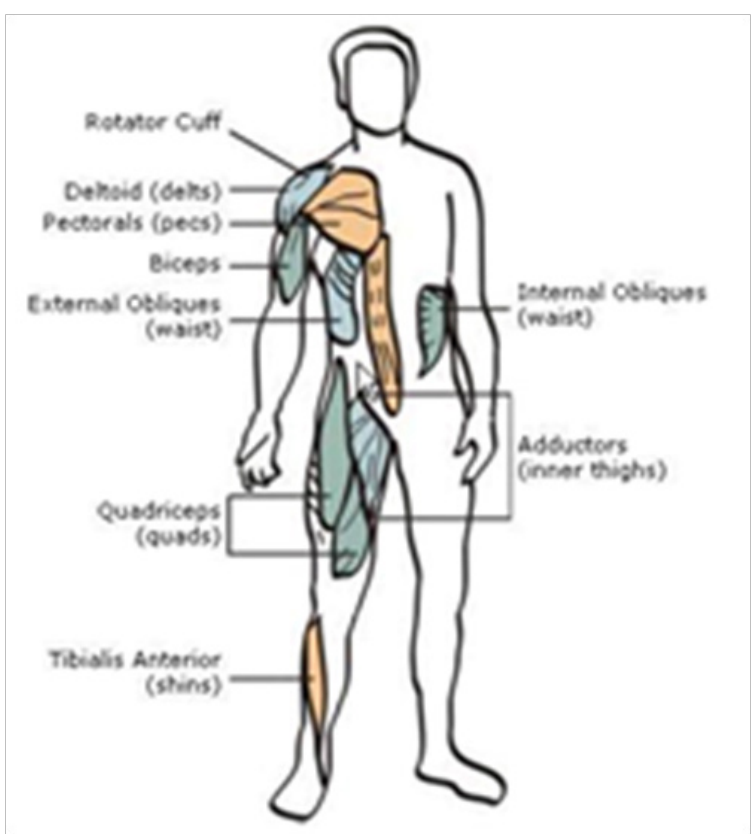

Figure 5 Location of front (a) and back (b) spot-site injections. ${ }^{24}$

Injectable steroid users face an increased risk of infection. This could be a result of poor injection practice, the use of non-sterile compounds/equipment and also the sharing of needles. ${ }^{11}$ This can lead to the development of bacterial and fungal abscesses as well as the transmission of blood-borne viruses such as hepatitis B or C and HIV. ${ }^{22}$ This risk of infection is not restricted to the use of AAS but applies to all illicit drugs that are administered via injection. Due to the large numbers of illicit users worldwide that has led to the establishment of needle exchange programs by many health organisations with the aim to "Reduce the transmission of HIV, Hepatitis and other infectious diseases, and contribute to the health of service users". ${ }^{14}$

\section{Stacking and cycling}

One way in which AAS are used is in a process known as "stacking" and simply involves the use of two or more different AAS at the same time. ${ }^{2}$ Many believe that stacking allows for the optimum results to be obtained and the AAS that are chosen to be incorporated into a "stack" are selected based upon their individual characteristics. For example, one AAS such as Anadrol may have the primary role of increasing mass and may be used in conjunction with Winstrol which has the primary function of strength. ${ }^{23}$ The most common way in which AAS are used incorporates stacking and is a process known as "cycling". Cycling is where the AAS are taken over a period of time and consists of an "on-cycle" and an "off-cycle" typically last 6-12 weeks. ${ }^{4}$ The "on-cycle" needs to be "...long enough for the body to enter an anabolic state and for diet and training to facilitate muscle growth and development". "The "on-cycle" will be followed by a period of time to allow the body to return to its natural state, this is known as post cycle therapy (PCT). PCT is then followed by the "offcycle" which is typically the length of the "on-cycle" and PCT and is a period of AAS-free training. ${ }^{11}$ There are two types of cycles that are used by athletes, each giving different results. In a "bulk cycle", the AAS used tend to be more androgen based and have the sole purpose of allowing the user to gain weight. ${ }^{24}$ In comparison to this, a "cutting cycle" uses less androgenic and retain less water which allows the user to obtain a more "cut" or "ripped" physique. ${ }^{11}$ AAS literature provides examples of hundreds of different cycles all which vary in complexity depending upon the required results, level of the AAS user and also gender, with some cycles having been developed specifically for women that possess lower virilising properties. ${ }^{25}$ However, they all share common features such as the use of oral AAS early on in the cycle, frontloading with powerful AAS at the start of the cycle to increase the blood testosterone levels quickly, the use of longer acting drugs to maintain these blood testosterone levels, and tapering the AAS use off gradually at the end of the cycle. With this in mind, to obtain optimal results, the cycle needs to be tailored to the individuals' metabolism and build. ${ }^{11}$ Examples to illustrate the difference in complexity of AAS cycles for beginners, intermediate and advanced users along with an advanced female cycle can be seen in Cycle 1-4 (Figure 6). ${ }^{25,26}$

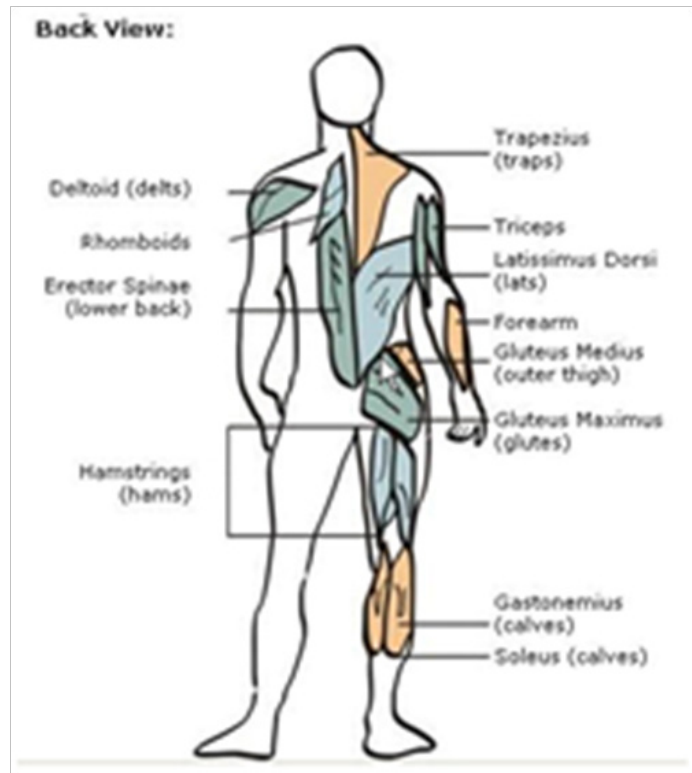

Figure 6 Adaptions of AAS cycles for beginners, intermediate and advanced users $^{27}$ along with an adaptation of an advanced AAS cycle for female users. ${ }^{25,26,51}$

\section{Polydrug use}

As mentioned previously, many users believe that stacking AAS can allow optimal results to be obtained..$^{23}$ In addition to this, many 
users also combine this with the use of other recreational/illicit drugs for the purpose of either further enhancing the effects of the AAS or to reduce the impact of the side effects (discussed in chapter 4). ${ }^{27}$ Table
3 shows some examples of drugs commonly used in conjunction with AAS (Table 3), ${ }^{4,27,28}$

Table 3 Adaption of drugs commonly used in conjunction with AAS and their proposed reason for use., 4,27,28,34,47

\begin{tabular}{|c|c|}
\hline Drug group & Reason for use \\
\hline Diuretics & To counteract fluid retention and \\
\hline Insulins & To promote glucose uptake by tiss \\
\hline Thyroid hormones & To accelerate fat metabolism \\
\hline Opiates & To reduce training-related pain in \\
\hline Human growth hormone (HGH) & To increase muscle and tendon str \\
\hline Tamoxifen & To prevent/reduce gynacomastia \\
\hline Human chorionic gonadotrophin (HCG) & $\begin{array}{l}\text { To promote the natural productio } \\
\text { on-cycle }\end{array}$ \\
\hline Cocaine/amphetamine & To enhance training \\
\hline \multicolumn{2}{|l|}{ Effects of taking steroids } \\
\hline \multicolumn{2}{|c|}{$\begin{array}{l}\text { It is common knowledge in today's society that there are adverse } \\
\text { effects associated with the use of AAS, yet many believe that the } \\
\text { perceived "benefits" greatly outweigh the risks. These "benefits" } \\
\text { include increased strength and muscle mass, decreased recovery } \\
\text { time, promotion of the healing of injuries and ultimately to obtain a }\end{array}$} \\
\hline
\end{tabular}

winning edge..$^{29}$ The adverse effects that are associated with the use of AAS are well documented throughout current literature. These effects are outlined in Table 4 and all differ in severity. Although for one anonymous All-Pro Lineman: "Anabolic steroids biggest side effect is loss of memory because no one can remember taking them" (Table 4). $3,4,11,19,22,27,30-32$

Table 4 Adverse Effects associated with AAS use. , $^{3,411,7,19,24,25,27-32,34,37}$

\begin{tabular}{|c|c|}
\hline Adverse effect & Comments \\
\hline \multicolumn{2}{|l|}{ Cosmetic } \\
\hline Acne & Particularly on the back but also on the face. Cystic types can leave permanent scarring. Effects observed in both sexes. \\
\hline $\begin{array}{l}\text { Water and Salt } \\
\text { Retention }\end{array}$ & Can cause skin puffiness and causes increase in blood pressure and increased strain on the kidneys. Effects observed in both sexes. \\
\hline Hair & $\begin{array}{l}\text { Male-pattern baldness is observed in both sexes with prolonged use and is often sped up with the use of AAS. The increased } \\
\text { growth of facial hair is also observed which is unwanted in female users. }\end{array}$ \\
\hline Gynaecomastia & $\begin{array}{l}\text { The development of abnormal breast tissue in male users due to an imbalance in the ratio of oestrogen to testosterone. } \\
\text { Gynaecomastia is permanent and is treated with surgery. }\end{array}$ \\
\hline \multicolumn{2}{|l|}{ Reproductive } \\
\hline Male & $\begin{array}{l}\text { AAS use supresses' natural production of testosterone which leads to testicular atrophy (shrinking of the testicles) and a reduction } \\
\text { in sperm production. These effects are reversed when AAS use stops. It has also been reported that AAS use can cause prostate } \\
\text { enlargement which causes problems urinating as well as users experiencing an increased libido. }\end{array}$ \\
\hline Female & $\begin{array}{l}\text { Increased libidos, disruptions to the menstrual cycle, and clitoral enlargement have all been reported by female AAS users along } \\
\text { with breast atrophy. }\end{array}$ \\
\hline \multicolumn{2}{|l|}{ Cardiovascular } \\
\hline $\begin{array}{l}\text { Heart Attack and } \\
\text { Stroke }\end{array}$ & $\begin{array}{l}\text { AAS use increases the levels of low-density lipoprotein (LDL) and decreases levels of high-density lipoprotein (HDL).This } \\
\text { increases the risk of atherosclerosis (fatty deposits that disrupt blood flow inside arteries) and can lead to a heart attack or stroke } \\
\text { depending on where the blood flow is disrupted. }\end{array}$ \\
\hline \multicolumn{2}{|l|}{ Hepatic } \\
\hline $\begin{array}{l}\text { Liver Tumours } \\
\text { and Dysfunction }\end{array}$ & $\begin{array}{l}\text { AAS use has been associated with liver tumours and peliosis hepatis (formation of blood-filled cysts on the liver) and has been } \\
\text { observed in both sexes particularly with the use of oral steroids. }\end{array}$ \\
\hline \multicolumn{2}{|l|}{ Musculoskeletal } \\
\hline Stunted Growth & $\begin{array}{l}\text { Particularly a problem with AAS use in adolescents. Sex hormones are responsible for triggering bone growth and abnormally high } \\
\text { levels can result in the bones stopping to grow prematurely. }\end{array}$ \\
\hline
\end{tabular}




\section{Steroids and the law}

In the UK AAS compounds are controlled as a Class C substance under the Misuse of Drugs Act (MDA) 1971 and are also scheduled under Schedule 4 Part II of the Misuse of Drugs Regulations 2001. It is not an offence under the MDA 1971 to possess AAS if they are intended for personal use and are in a medicinal form. It is, however, an offence to produce, supply or possess/import/export with intent to supply without a licence. ${ }^{33}$ The penalties AAS carry are 2 years imprisonment and an unlimited fine for possession and 14years imprisonment and an unlimited fine for supply. ${ }^{34} \mathrm{AAS}$ are also licenced under the Medicines Act 1968 as prescription-only medicines by the Department of Health's Medicine Control Agency making it illegal for a doctor/pharmacist to supply AAS in any other way than with doctor's prescription. ${ }^{35}$ The term "medicinal product" is one that has caused confusion amongst law enforcement and users and is defined by the European Directive 2001/83/EC as:

I. Any substance or combination of substances presented as having properties for treating or preventing disease in human beings; or

II. Any substance or combination of substances which may be used in or administered to human beings either with a view to restoring, correcting or modifying physiological functions by exerting a pharmacological, immunological or metabolic action, or to making a medical diagnosis". ${ }^{36}$

Changes to the law that came into effect on 23rd April 2012 removed the term "medicinal product" from the legislation. ${ }^{37}$ It is still legal to import/export for personal use, however, this must be carried out in person as import restrictions that have been put in place now make it illegal import/export AAS using postal, courier or freight services. ${ }^{38}$ Martin Chandler of Liverpool John Moores University believes that this chance that was brought into effect in the run up to the London 2012 Olympic Games will: “...cause a rise in home produced products by illicitly sourced raw testosterone powders, so we'll see a rise in underground products produced in the UK, this is likely to decrease the quality and increase the risk..... and this year in particular there is a crackdown on raw materials as the government have to be seen to be preventing the importation and production of anabolic steroids prior to the Olympics". ${ }^{37}$

\section{Steroid seizures}

The number of AAS seizures between 2009/10 and 2013/14 as reported by the Home Office can be seen in Table 5 below. The data in the table highlights that there was a drop in the number of AAS seizures between the years 2009/10 and 2010/11 but from 2010/11 to 2013/14 the number of AAS seizures has almost doubled which suggests that AAS use is a growing problem here in the UK (Table 5). ${ }^{39-43}$ The statistics used to produce Figure 7 are published by the Home Office for each financial tax year which means that the import restrictions mentioned previously were introduced shortly after the start of the 2012/13 financial tax year. The sharp increase (44\%) in the number of seizures made by the UK Border Force in 2012/13 compared to 2011/12 could therefore be a result of the introduction of these import restrictions in the run up the London 2012 Olympics. There is no obvious reason for the $56 \%$ decrease in the number of seizures by the UK Border Force that is observed between the years 2009/10 and 2010/11 (Figure 7). ${ }^{39-43}$ In comparison to the number of AAS seizures, Figure 8 below shows the proportion of AAS seizures for the Police and UK Border Force in terms of the quantity of AAS seized. In all 5 years displayed in Figure 8 it can be seen that the majority of the quantity of AAS seized in each year was by the UK Border Force. This could suggest that people are dealing in AAS as they are importing quantities that are much greater than those required for personal use. It can also be seen from Figure 8 that for the year $2012 / 13$ there is a significantly lower amount (55\%) of AAS seized by the Police in comparison to that of the UK Border Force which again could be a result of the introduction of the import restrictions and the UK Border force cracking down on this (Figure 8). ${ }^{39-43}$

Table 5 Home office reported figures for the number of AAS seizures and the quantity of AAS seized between the years $2009 / / 0$ and $20 / 3 / \mid$ 4, $4,14-16,39-43$

\begin{tabular}{ll}
\hline Year & Number of seizures \\
\hline $2009 / 10$ & 871 \\
$2010 / 11$ & 674 \\
$2011 / 12$ & 706 \\
$2012 / 13$ & 836 \\
$2013 / 14$ & 1142 \\
\hline
\end{tabular}

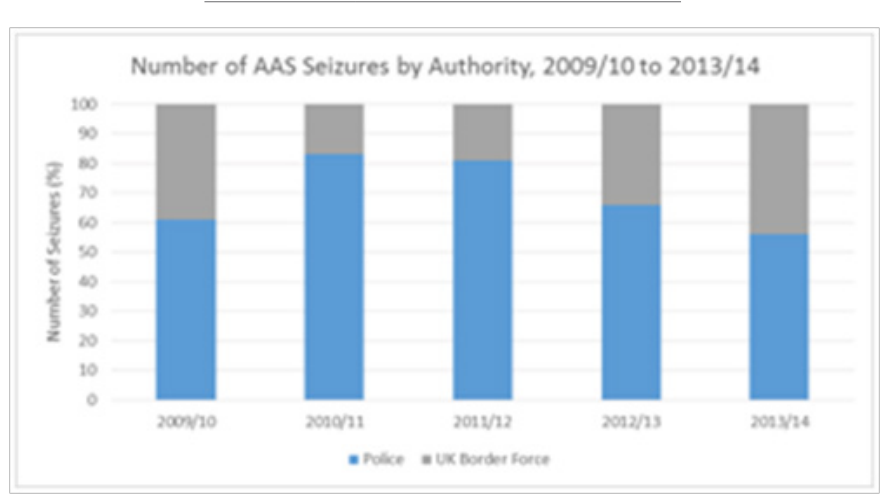

Figure 7 Percentage number of AAS seizures by authority between 2009/10 to $2013 / / 4$. $^{4,14-16,39-43}$

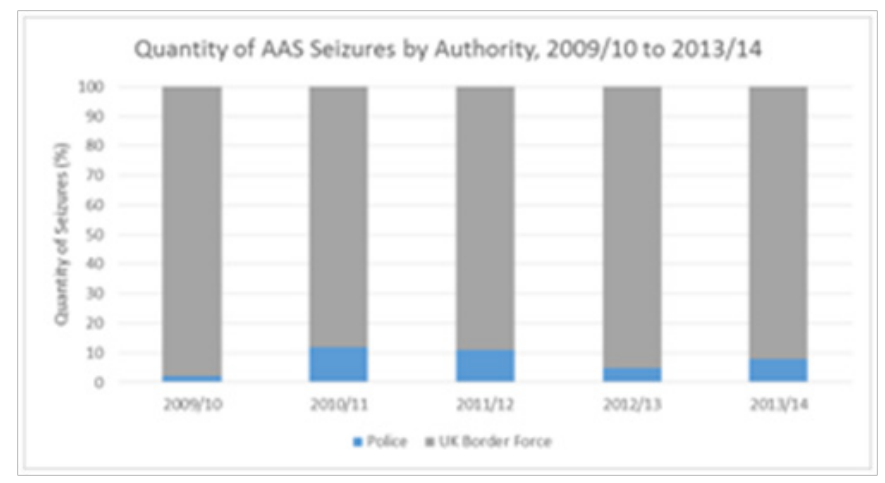

Figure 8 Proportion of AAS seizures by authority in terms of quantity seized between $2009 / 10$ to $2013 / / 4$., $^{4}, 14,39-43$

\section{Use of steroids in the sport industry}

The desire to succeed and the feeling of euphoria that comes hand in hand with victory is the driving force of many athletes and to some, this is worth virtually any sacrifice. ${ }^{3}$ It is my opinion that an athlete's desire to find a shortcut to success leaves them with little regard for the moral implications of doping in sport. Not only is the use of performance enhancing drugs in general, not specifically AAS, unfair but it creates an uneven playing field that make it impossible for some 
to compete on. The use of AAS can have a serious impact, not just on the health of the athlete as mentioned previously, but the repercussions of being caught abusing AAS can result in a ban from competing and even having any medals or titles won as a result stripped. The use of AAS was initially confined to the power disciplines such as the throwing events (javelin, discus, shot-put and hammer) along with weightlifting and body building but their use soon spread to other disciplines where an increase in size, speed or strength would be advantageous. ${ }^{19}$

\section{History of the use of steroids}

The observation that the testes were vital for masculinisation can be dated back as far as the fifteenth century BC. At this time, in India, it was believed that consuming the testes of animals was a cure for impotence "...while in ancient Greece, Aristotle wrote that castrating immature male birds affected secondary sexual characteristics". ${ }^{44}$ By the mid-eighteenth century John Hunter, a Scottish surgeon, transplanted the testes of a rooster into its abdominal cavity and it was observed that the effects of castration were reversed. However, it was not until 1935 that the crystalline testosterone was isolated and it is from this that the whole concept of AAS stems. ${ }^{44}$ The use of performance enhancing drugs (PEDs) in sport is perceived by many to be a problem that is somewhat new. In reality, however, the use of substances to give an athlete an advantage over an opponent can be dated back as far as to the ancient Greeks. ${ }^{27}$ Some believing that: “...it wasn't too long after the very idea of sport was conceived that athletes learned about the shortcuts to victory, meaning they learned how to cheat". ${ }^{3}$ A brief outline of the key points in the history of the development and use of PEDs in sport can be seen in Table 6, some of which are discussed in more detail later in this chapter. It was not until after the Second World War (1939-1945) that the use of drugs in sport became wide-spread. The Second World War marked a time where the use of amphetamines and AAS was extensive by the military which "...not only greatly increased scientific knowledge about the properties of the various drugs but also demonstrated the widespread opportunities for the use of the drugs outside a therapeutic context" Table $6 .^{1-3,45-47}$

Table 6 Adaption of an overview of the key points in the history of the development and use of peds in Sport. ${ }^{1-3,19,36,45-48,59,31}$

\begin{tabular}{|c|c|}
\hline Time & Development/use of PEDs \\
\hline I5th century BC & In India they believed that consuming the testes of an animal was a cure for impotence \\
\hline Ancient Egyptians & Used the ground rear hooves of the Abyssinian ass as they believed it enhanced their performance \\
\hline Roman gladiators & Used stimulants to overcome fatigue \\
\hline Ancient Olympians & Bread soaked in opium, mushrooms, strychnine \\
\hline 1935 & Crystalline testosterone was isolated by Laqueur \\
\hline World War II & $\begin{array}{l}\text { Amphetamine used to counter fatigue among soldiers and pilots. Testosterone used to increase aggressiveness and strength of } \\
\text { German soldiers }\end{array}$ \\
\hline 1950 & AAS introduced in sport, Dr Ziegler aided CIBA Pharmaceutical Company in the development of Dianabol \\
\hline 1960 Olympics & First documented fatality as a result of doping - amphetamine induced heatstroke \\
\hline 1964 & IOC bans doping for Olympic athletes \\
\hline $1966-1972$ & $\begin{array}{l}\text { East Germany introduces a secret national system for hormone doping for athletes of both sexes with methandrostenolone and } \\
\text { state-manufactured oral-turinabal }\end{array}$ \\
\hline 1967 & Death during Tour de France as a result of doping, IOC adopts a drugs testing policy \\
\hline 1970 & Diuretics used to dilute urine prior to drugs testing \\
\hline 1974 & AAS added to the IOC list of prohibited substances \\
\hline I976 Olympics & Suitable test for AAS developed which allowed for an enforceable ban \\
\hline Up to 1980 & Amphetamine, caffeine, cocaine and strychnine dominate doping incidents \\
\hline 1980 & The misuse of $\mathrm{HGH}$ appears, $\beta$-blockers used to improve shooting, AAS use spread among many different sports \\
\hline 1988 & $\begin{array}{l}\text { Ben Johnson became the first Olympic gold medal winner in track and field to be stripped of his medal after testing positive for } \\
\text { stanozolol }\end{array}$ \\
\hline 2000 & Development of tetrahydrogestrinone (THG or "the clear"), an AAS designed to escape detection in doping analysis \\
\hline 2007 & Marion Jones admits having taken "the clear" and is stripped of 5 gold medals \\
\hline 2012 & $\begin{array}{l}\text { Lance Armstrong stripped of all seven tour de france titles won from 1999-2005 and given a lifetime ban by the international } \\
\text { cycling union }\end{array}$ \\
\hline 2013 & Lance Armstrong stripped of Olympic bronze medal from 2000 Sydney games \\
\hline
\end{tabular}

\section{Olympic success}

In the early 1950 s there were rumours of hormonal experiments taking place by the Soviet Union to enhance the performance of their athletes. ${ }^{3}$ The Soviets returned to Olympic competition at the 1952 Helsinki Games and did so with great success which sparked three decades of rivalry for domination of the Olympic medal table. ${ }^{1}$ At the 1956 World Games in Moscow, Dr Ziegler, an American physician, 
witnessed the use of AAS, in this case straight testosterone, among Soviet athletes. ${ }^{3}$ Dr Ziegler knew that the use of AAS would result in the enlargement of the prostate gland obstructing the urinary tract and so was not surprised to see that Soviet athletes were being catheterised to enable them to pass urine. 3 Perhaps one of the best examples of the wide-spread government-sanctioned drug use by athletes is the case of the former German Democratic Republic (GDR). The GDR exploited sport "... for purposes of international prestige or diplomatic advantage..." and succeeded, being consistently at the top of the medal tables, along with the US and the Soviets, finishing third in 1972 and second in 1976, 1980 and 1988. ${ }^{1}$ According to Manfred Höppner, the Deputy Director and Chief Physician of the GDR doping system, almost all medal-winning GDR athletes in events involving speed or strength at the 1972 Munich Olympic Games had been administered Oral-Turinabol, an AAS. ${ }^{48}$ Following reunification, and the lapse of the doping system, the performance of GDR athletes dropped significantly and it is now widely acknowledged that the GDRs success was largely a result of the government-sanctioned drug program. ${ }^{1}$ It was not until the 1976 Montreal Olympics when the first a suitable test for AAS in urine was developed which allowed for an enforceable ban. ${ }^{2}$ This ban, coupled with the advancement in drug testing, resulted in the disqualification of eleven athletes, eight of which were disqualified for the use of AAS. ${ }^{1}$ Despite the introduction of drug testing for AAS, their use continued to be a problem in elite sport, so much so that the 1980 Moscow Olympics were nicknamed the "Junkie Olympics". ${ }^{1}$ It soon became clear that athletes were one step ahead of the scientists as: "The athletes would catheterize themselves first to drain their own drug-tainted urine from their bladders, then to pump bogus, "clean" urine into their bodies, which they would pass when tested. This process enabled many athletes to beat the tests; it is still used today by athletes trying to avoid detection". ${ }^{3}$ By the late 1980 s it was estimated that $70 \%$ of all positive drug tests conducted at IOC accredited laboratories were for AAS showing just how wide-spread a problem they had become. ${ }^{1}$ Up until 1988 I feel that the problem of AAS use in sport was one that was confined to the knowledge of those directly involved in the sport industry; the athletes, the coaches and the governing bodies of sport such as the IOC. However, in 1988 at the Seoul Olympics something happened that exposed the problem of AAS use to the general public world-wide.

\section{Ben Johnson}

Benjamin Sinclair (Ben) Johnson was born in Jamaica and immigrated to Canada at the age of 14 . He was quick to establish a promising track career and became a known athlete after he won a bronze medal at the 1984 Los Angeles Olympics. ${ }^{49}$ At the 1988 Seoul Olympics, Johnson won the gold medal in the men's $100 \mathrm{~m}$, beating his biggest rival, Carl Lewis, and setting a world record time of 9.79 seconds. Ben Johnson immediately became a national hero, but this all changed three days later when it was announced that he had tested positive for stanozolol, an AAS banned by the IOC. ${ }^{50}$ Johnson was stripped of his gold medal, his world record was rescinded and he was suspended from competing for two years. This resulted in Lewis been promoted to first place, retaining his title, and Linford Christie was promoted to the silver medal position. ${ }^{51}$ Overnight, Johnson went from national hero to national disgrace ${ }^{49}$ and even to this day is "... still branded the most notorious cheat in sporting history". ${ }^{52}$ "That $100 \mathrm{~m}$ race at the 1988 Seoul Olympics has since become known as "the dirtiest race in history" ${ }^{\circ 0}$ with a further five of the eight finalists been implicated in various drug scandals over the years. This included Lewis who, it emerged, had tested positive for stimulants during the
U.S. trials yet it was Johnson that remained the figurehead of the drug cheat.$^{50}$ Comparing the image of Johnson at the 1982 Commonwealth Games (Figure 9) to that of Johnson at the 1988 Seoul Olympics (Figure 10) it is evident that there is a distinct difference in muscle definition and development between the two photos which leads to suspicions of AAS abuse. Johnson has since admitted to using AAS since $1981^{51,53,54}$ having been encouraged to do so by his coach, Charlie Francis.

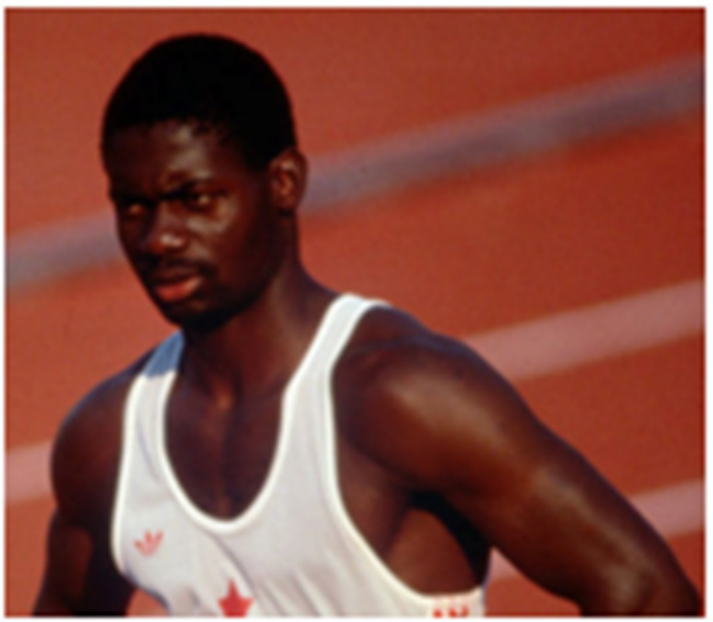

Figure 9 Ben Johnson at the 1982 Commonwealth games. ${ }^{46}$

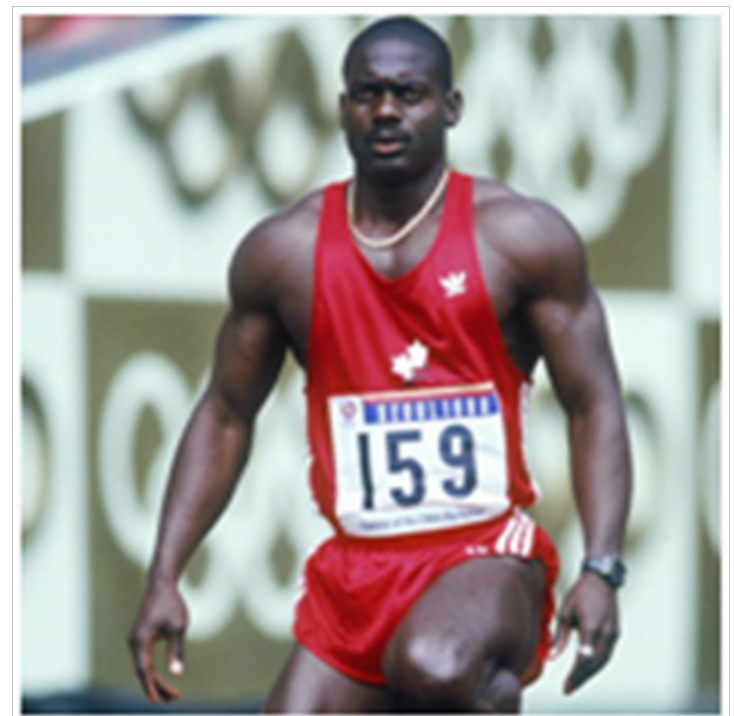

Figure 10 Ben Johnson at the 1988 Seoul Olympic Games. ${ }^{58}$

Although he refuses to place any blame on Francis, ${ }^{52}$ Johnson recalls: "Charlie said over a few conversations, that you only cheat if you're the only one doing it. This means if the other guys are doing it, and you start doing the same thing, it's not cheating" ${ }^{52}$ It is speculated by many that Johnsons determination to beat his rival, Lewis, to the gold medal lead to Johnson and his coach taking the risk of administering an extra dose of AAS too close to the 1988 Seoul Olympics. ${ }^{51}$ However, this is something that Johnson protests. He believes that some corporate force did not want him the win the race and so paid for him to be framed by spiking a drink he drank sometime before the race with stanozolol, an AAS that he claims he has never used.52 "I stopped taking steroids six weeks before 
the Games. I wouldn't be that dumb to take anything so close to an Olympic final. And the amount of steroids found in my system could have killed a normal man. I tested positive for stanozolol but I was using other steroids". ${ }^{52}$ In 2013, 25 years after he was stripped of his gold medal, Johnson still feels that he was treated unfairly in a time when drug use in sport was a wide-spread problem. ${ }^{50} \mathrm{He}$ said: "I was nailed on a cross, and 25 years later I'm still being punished. Rapists and murderers get sent to prison, but even they get out eventually. I know what I did was wrong. Rules are rules. But the rules should be the same for all. But politics always plays in sports". ${ }^{55}$

\section{Marion Jones}

Marion Jones displayed talent at an early stage. Her family moved numerous times during her teenage years to enable her to compete in prominent teams and she was competing on an international level at the age of $12 .{ }^{56}$ At the 2000 Sydney Olympic Games, Marion Jones became the first woman to win five medals in single Games, winning three gold medals and two bronze. Jones became the golden girl of athletics overnight. ${ }^{13}$ However, suspects of AAS use had surrounded Jones throughout most of her career and the difference in appearance of Jones from before and during the 2000 Sydney Olympics can be seen in Figures $11 \& 12$ respectively.

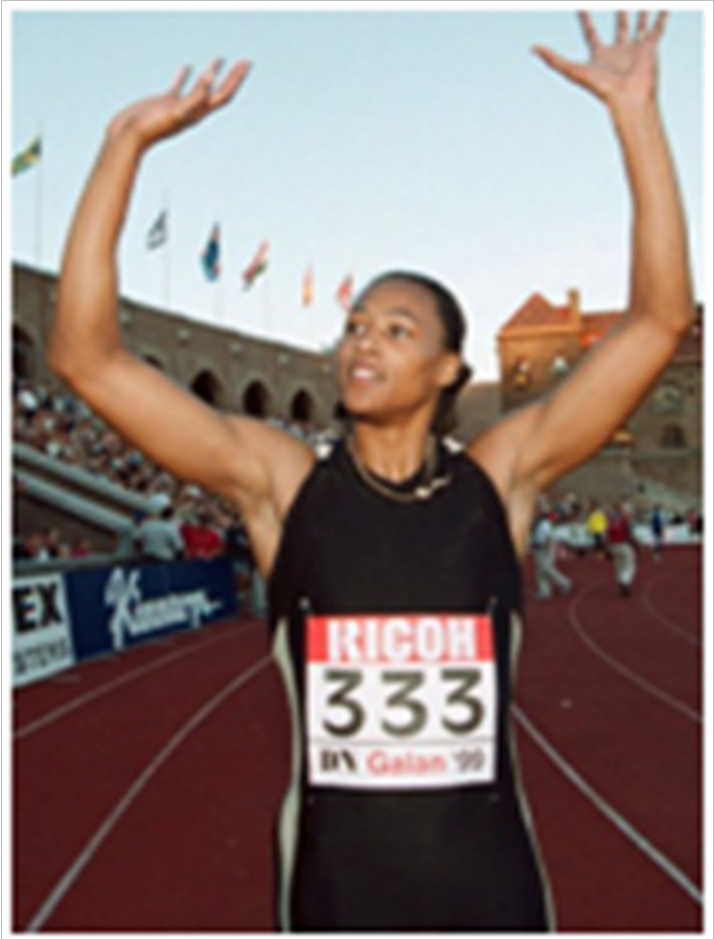

Figure I I Marion Jones in 1999, before the 2000 Sydney Olympic Games. ${ }^{10}$

It was not until 2003 that allegations that Jones had used prohibited substances were made by her ex-husband, C.J. Hunter and the founder of Bay Area Laboratory Co-operative (BLACO), Victor Conte. ${ }^{56}$ These allegations came about when Jones' former coach, Trevor Graham, sent a syringe containing the previously undetectable THG ("the clear") to the US Anti-Doping Agency (USADA). Raids on the BLACO headquarters linked Jones to doping schedules, purchases and blood test results. ${ }^{13,57,58}$ Jones then went on to begin training with Charlie Francis, the former coach of Ben Johnson, in the run up to the 2004 Athens Olympics, which lead to five-time Olympic gold medallist
Michael Johnson commenting that: "The people she has surrounded herself with have been involved in some of the largest drug scandals in the sport". ${ }^{13}$ In 2004, Conte stated on national television that he has observed Jones injecting herself with $\mathrm{HGH}$ and that he had personally given her five different PEDs before, during and after the 2000 Sydney Olympics which lead to the IOC launching an investigation. ${ }^{59}$ As well as this, it was known to the public that Hunter that at the 2000 Sydney Olympics he had personally injected her with THG ${ }^{56}$ A few years later in 2006, Jones tested positive for a prohibited substance but this was later cleared by a second test. ${ }^{56}$ In 2007 , Jones finally admitted to lying to agents in 2003 about her use of THG and was sentenced to six months imprisonment for this in $2008 .{ }^{56}$ In a letter sent to family and friends on the eve of the trial Jones claimed that she never knew she was taking a prohibited substance and that he coach, Graham had her believe that it was flaxseed oil. ${ }^{60}$ The outcome of this for Jones could be considered humiliating but many would say she got what she deserved. Apart from serving six months in prison for lying to a federal agent, the IOC (International Olympic Committee) stripped Jones of all five medals she had won at the 2000 Athens Olympics and the International Association of Athletics Federations, the international governing body of track and field, “....annulled all of Jones's results since September 2000...".22 Jones' claims to ignorance regarding the substances Graham was giving her do not get her any sympathy in the eyes of some. In an era of sport where PED use is becoming ever more prevalent, it is hard to believe that any athlete who wants to remain clean would take any substance given to them without knowing for certain its identity. Coupling this with the fact that she has knowingly associated herself with people who have previously been involved in drug scandals further enhances the belief that it was her intention to dope all along.

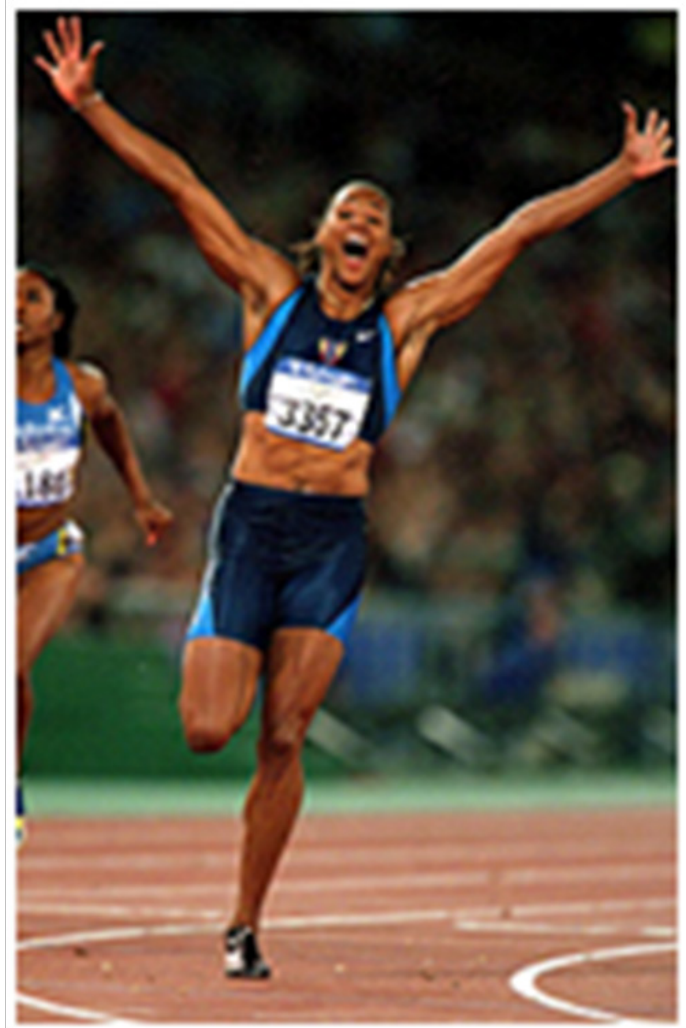

Figure I 2 Marion Jones in 1999, before the 2000 Sydney Olympic Games. ${ }^{10}$ 


\section{Lance Armstrong}

Lance Armstrong, like many athletes, showed talent at a young age. At the age of 13 he won the Kids Iron Triathlon, and winning $\$ 20,000$ in a Triathlon at the age of $15 .{ }^{21}$ By the age of 18 , Armstrong had begun training with the U.S. Olympic cycling development team. ${ }^{12} \mathrm{He}$ soon became the "The Golden Boy of American Cycling" four years later when he won ten titles and in 1996 was the world top ranked cyclist. ${ }^{21}$ On 2nd October 1996, however, devastation struck when Armstrong was diagnosed with testicular cancer. He underwent surgery to remove the malignant testicle but it was revealed that the cancer had spread to his lungs, lymph nodes, abdomen and brain. Armstrong underwent surgery later that month to remove two cancerous lesions from his brain. ${ }^{12}$ Armstrong made a full recovery and returned to cycling, saying before the 1999 Tour de France that: "I think that if I were to come back and to win and to be successful, I would consider that a complete recovery". ${ }^{57}$ Armstrong began secretly visiting physician Michele Ferrari who had a reputation for the use of doping. ${ }^{57}$ This lead to one Sunday Times reporter, David Walsh, referring to the relationship between Armstrong and Ferrari as: "You keep doing your job as Frankenstein and I'll be the best monster you've ever created". ${ }^{57}$ Armstrong went on to win the 1999 Tour de France and it was here that suspicions of Armstrong's doping grew among professional cyclists when the relationship between Armstrong and Ferrari became more open. It was published in the press that Greg LeMond, winner of the Tour de France in 1986, 1989 and 1990, ${ }^{57}$ had said that: "In a general sense, if Lance is clean, it is the greatest come back in the history of sport. If he isn't, it would be the greatest fraud" ${ }^{61}$ For the next six consecutive years Armstrong won the Tour de France, securing his place in the history books with seven Tour de France titles to his name Figure 13. He also won a bronze medal at the 2000 Sydney Olympics. Having achieved this, Armstrong then announced his retirement from cycling but later returned in 2009 , placing third in the Tour de France that year. However, this return was short lived as he announced his retirement yet again in February 2011, under a cloud of allegations of PED use ${ }^{20}$ Figure 13.

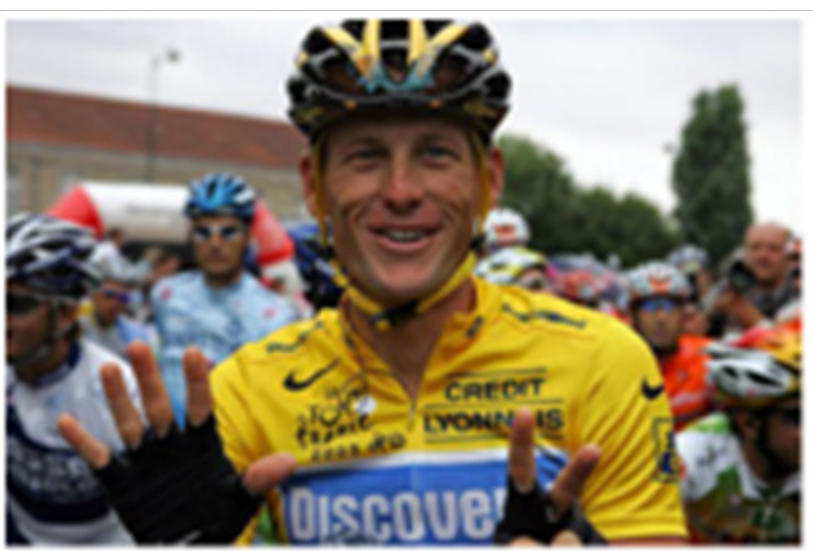

Figure I 3 Lance Armstrong after winning his seventh Tour de France title. ${ }^{40}$

Lance Armstrong after winning his seventh Tour de France title. ${ }^{40,62-64}$ Something people had suspected for years was confirmed in June 2012 when USADA charged Armstrong with the use of PEDs describing him as "....ringleader of the most sophisticated and professional doping program sport has ever seen". ${ }^{30}$ USADA also released a lengthy report "... that detailed eyewitness accounts of Armstrong not only using performance-enhancing drugs, but also coercing teammates to do so to". ${ }^{21}$ USADA stripped Armstrong of all seven of his Tour de France titles in 2012 and banned him from cycling for life. In 2013 the IOC also stripped him of the bronze medal he won at the 2000 Sydney Olympics. Also in 2013, Armstrong finally admitted to the use of testosterone, EPO and blood doping in the mid1990s and said that they contributed to all seven of his Tour de France titles in an interview with Oprah Winfrey. ${ }^{21}$ Armstrong became "sports most infamous drugs cheat". ${ }^{30}$ However, an interview broadcast by the BBC in January 2015 gave an in-depth view of Armstrong's feelings on past events and his future. When asked about the financial strain that the drug scandal had placed on him, resulting in him having to sell his house, ${ }^{30}$ Armstrong said: "Nobody's going to feel sorry for me if the number is $\$ 1$ or $\$ 100$ million". ${ }^{30}$ The "deepest cut" for Armstrong was when the cancer research charity he established in 1997 after his recovery from cancer, the Lance Armstrong Foundation, severed its ties with Armstrong..$^{21,30}$ The charity has raised over half a billion dollars to date and sold over 85 million of the famous yellow wrist bands (Figure 14) but when news of Armstrong's doping surfaced, the foundation renamed itself the Livestrong Foundation.

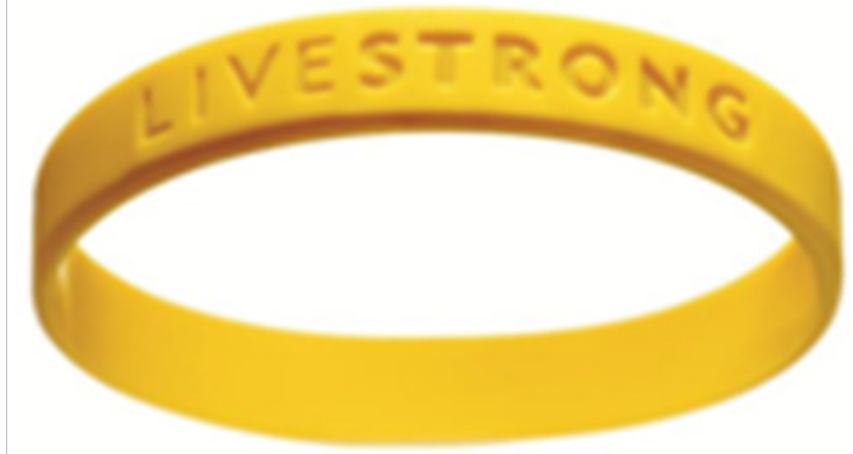

Figure 14 Famous yellow wrist bands sold by the Livestrong Foundation (formally the Lance Armstrong Foundation). ${ }^{35}$

Armstrong remains proud of his seven yellow jerseys, all of which are displayed on the walls of the cycling shop he owns in Austin, Texas. He believes that the era in which they were won was one in which doping was a common practice among professional cyclists. ${ }^{30}$ This is supported by the words of one of Armstrong biggest rivals, Jan Ullrich. Ullrich admitted to the use of EPO throughout his career a few months after Armstrong confessed to Oprah. ${ }^{49} \mathrm{He}$ said: "In my view you can only call it cheating on my part when it is clear that I have gained an unfair advantage... That was not the case. All I wanted was everyone to have the same chances of winning edge". ${ }^{49}$ This statement by Ullrich further supports Armstrong's view that doping is commonplace in cycling, as does the fact that the winners title has not yet been awarded to any other riders in the race. ${ }^{49}$ It is the opinion of some that given that all the top riders are suspected of using doping and many have been proven through positive drugs test results, in some respects, Armstrong won the seven Tour de France titles on a level playing field. However, this does not condone Armstrong's actions. Many people believe that the winners titles for the seven years in which Armstrong won should be awarded to someone else, however, there is speculation as to just how far down the ranking you would have to go to reach a rider that you were sure had not used PEDs. ${ }^{49}$ Armstrong himself said: "I think if I'm not the winner, I think there has to be a winner...I'm just saying that as a fan... If you go to the [list of Tour de France winners] for [the last] 100years, you know there's this huge block in World War I, there's no winners. World War II, there's no winners and then all of a sudden it's almost like 
there's another World War. There has to be a winner". ${ }^{30}$ As mentioned previously, Armstrong was given a lifetime ban from cycling by USADA and many believe that he got what he deserved. However, it should be noted that many others were charged by USADA for violating the same rules and using the same substances, yet they received much smaller penalties (six months to two years typically) which is most probably a result of Armstrong's refusal to co-operate with USADA. ${ }^{30,49}$ What many people want to see from Armstrong is evidence that he is sorry for his actions and in some instances he has shown remorse. In interviews he has openly admitted that he is happy to be made an example of if it will eventually lead to his forgiveness and earning back some trust. Yet it is hard to truly believe his remorse when, for years, he has point blank denied any allegations of PED use. He has said that he would not necessarily change the decisions he made, only the way in which he treated others involved. And to top it all off, he would do it again. ${ }^{30}$ "If I was racing in 2015, no, I wouldn't do it again as I don't think you have to do it again. If you take me back to 1995 , then it [doping] was completely and totally pervasive, I'd probably do it again. People won't like to hear that... [but] that's the honest answer". ${ }^{30}$ It is the opinion of some that this admittance by Armstrong, that he would probably dope again, highlights the power that PEDs have over athletes. Athletes are, in a sense, addicted to winning and will do anything within their power to ensure that they are victorious and appear to pay little attention to the consequence if they get caught.

\section{Conclusion}

This literature review confirms that the objectives, to provide an overview of AAS and their use and impact within the sports industry, have been established and information detailing the basic chemical structure and nomenclature of an AAS molecule have provided a basic background of the drugs along with the mechanism in which they work. The different types of AAS, namely oral and injectable, have been discussed and it has been highlighted how modifications to the basic structure of an AAS molecule determines the most effective route of administration. The advantages and disadvantages of oral and injectable AAS are shown with regard to the speeds at which they have an effect upon the body, their detection times and the adverse side effects that they have upon the body. It is clear from the research conducted during this review that the speed of effect and the detection times are the two factors that are the most important to an AAS user, especially when you factor in the possibility of drugs testing. This turns AAS use into a complex equation for athletes whose optimal goal is to use AAS to enhance their performance but the vital component is to avoid detection. With regard to the impact of AAS use upon the body, polydrug use is not uncommon with AAS users taking other drugs alongside AAS to either increase the perceived "benefits" or to reduce the side effects. However, little research has been conducted into the long-term effects of AAS use such as the increased risk of a heart attack or stroke which are, at present, only associated with prolonged AAS use. It would be recommended that this is an area greatly in need of further research to establish causation. Along with this, further research in this area would allow health care professionals to provide more accurate information to AAS users and further address the medical problems caused by AAS use. However, due to the underground nature of AAS abuse, it is understandable that this may be difficult and the reluctance of users to admit use plays a key role.

With regard to the effect that oral AAS have upon the liver, there is evidence to suggest that, to some extent, users take this into consideration. It is understood from the way in which stacks and cycles are employed that oral AAS tend to be used at the beginning of a cycle. This is partly due to them having an effect upon the body much more quickly than injectable AAS but is mainly due to users understanding of the damage that prolonged use of oral AAS can have upon the liver.

This review has also provided an in-depth view of the use of AAS in the sports industry and highlights that, although AAS use was initially confined to the power disciplines, their power as a performance enhancer has now been realised and they are now used in just about every sport where an increase in strength, speed or size would be considered advantageous. Furthermore, the profiles of what are considered by many to be three of the most high profile drug cheats in sporting history have been examined. Ben Johnson, Marion Jones and Lance Armstrong were all once considered to be one of sporting's greats but this all changed when they were exposed as drug cheats. The impact that this exposure has had upon the spectators of sport is one that has changed the shape of sport forever. Now, when spectators witness a remarkable performance they do so with much more scepticism. With the sheer number of drug scandals that are constantly in the press, some of which are exposed decades after the event, it is understandable how spectators themselves are feeling cheated. It is clear that the presence of anti-doping agencies such as WADA, is not enough of a deterrent to athletes to prevent them from doping. It is well known that athletes are now drug tested out of season in addition to the in season testing and a recommendation to address this problem could be to review the anti-doping policy and amend these so that the frequency of drugs tests on athletes is much higher. In addition to this, a reduction in the amount of notice given to athletes before a drug test could be reduced which would increase the chances of any traces of a PED still being in the athletes system.

\section{Acknowledgments}

None.

\section{Conflicts of interest}

The author declares that there are no conflicts of interest.

\section{References}

1. Advisory Council on the Misuse of Drugs (ACMD). Consideration of the Anabolic Steroids. Advisory Council on the Misuse of Drugs, London, UK. 2010

2. Anabolics. Detection Times of Steroids. Anabolics.com. 2015.

3. BBC sports. Marion Jones's fall from grace. UK. 2008.

4. Dhani A. Seizures of Drugs in England and Wales, 2013/14. Home Office, UK. 2014;18.

5. BBC Sports. Lance Armstrong stripped of Tour wins. 2012.

6. Beststeroidscycle.com. How to Get Rid of Man Boobs: Gynectrol Review. 2015

7. British Medical Association (BMA). Drugs in Sport: The Pressure to Perform. BMJ Books, London, UK. 2002.

8. Bond D. Marion Jones finally confesses to steroid use. 2007.

9. Brunsdon N. Changes to Steroid Laws. UK. 2012.

10. Business insider. Marion Jones before the Olympics. 2013.

11. Chandler M. Performance \& Image Enhancing Drugs in Syringe Exchange: Implications for Practice. Liverpool John Moores University, UK. 2008. 
12. CNN. Lance Armstrong Fast Facts. USA. 2015.

13. Coleman K. Seizures of Drugs in England and Wales, 2010/11. 2nd ed. Home Office, UK. 2011;38.

14. Coleman K. Seizures of Drugs in England and Wales, 2011/12. 2nd ed. Home Office, UK. 2012;37.

15. Coleman K. Seizures of Drugs in England and Wales, 2012/13. Home Office, UK. 2013;17.

16. Davis A. Medicines by Design. U.S. Department of Health and Human Services. NIH Publication, USA. 2006;12.

17. Drug scope. Drug laws. UK. 2015.

18. Duchaine D. Underground steroid handbook I. HLR Technical Books, Venice, USA. 1989;95.

19. Houlihan B. Dying to win: doping in sport and the development of anti-doping policy. 2nd ed. Strasbourg, Council of Europe Publishing. $2002 ; 240$.

20. Infoplease. Lance Armstrong. USA. 2013.

21. Encyclopedia Britannica. Marion Jones: American athlete. 2014.

22. ESPN. Ben Johnson: drug cheat. 2015.

23. Flemen K. Performance Enhancing Drugs Resource Pack 2011. 4th ed. KFx. 2011;85.

24. Flemen K. Safer Injecting Resource Pack. KFx. 2008;128.

25. Franke W, Berendonk B. Hormonal doping and androgenization of athletes: a secret program of the German Democratic Republic government. Clin Chem. 1997;43(7):1262-1279.

26. Hardcore Bodybuilding. Complete Steroid Handbook. 2004 ed. Hardcore Bodybuilding. 2003.

27. U.S. Department of Health and Human Services. Anabolic Steroid Abuse. Research Report. National Institute on Drug Abuse, USA. 2001;3.

28. Hough DO. Anabolic steroids and ergogenic aids. Am Fam Physician. 1990;41(4):1157-1164.

29. BBC News. Lance Armstrong: The Road Ahead. 2015.

30. Voy R, Deeter K. Drugs, sport and politics. The inside story about drug use in sport and its political cover-up, with a prescription for reform. Champaign, Leisure Press, USA. 1991.

31. Yesalis C. Anabolic steroids in sport and exercise. 2nd ed. Champaign, Human Kinetics, USA. 2000

32. Lenehan P, Miller T. Anabolic Steroids A guide for users \& professionals. Manchester, Lifeline Publications, UK. 2004;35-42.

33. McVeigh J, Evans-Brown M. An introduction to anabolic steroids. Sport EX Medicine. 2008;38:20-26.

34. Livestrong Foundation. Livestrong Wristbands, 10 Pack - X-Small/ Medium. 2015.

35. Mail Online. Lance Armstrong gives back medal to International Olympic Committee. UK. 2013.

36. Maravelias C, Dona A, Stefanidou M, et al. Adverse effects of anabolic steroids in athletes. Toxicol Lett. 2005;158(3):167-175.

37. Mc Rae D. Ben Johnson: My revelations will shock the world. UK. The guardian. 2010.
38. Medicines and Healthcare products Regulatory Agency (MHRA). A Guide to What is a Medicinal Product. 1st ed. Medicines and Healthcare products Regulatory Agency, London, UK. 2012;12-13.

39. Mirror. Seven 'wins' - but none of them clean. 2013.

40. Mottram D. Drugs in sport. 4th ed. Routledge, London, UK. 2005.

41. Mulchandani R, Hand T, Panesar L. Seizures of Drugs in England and Wales, 2009/10. Home Office, Forthcoming publications, UK. 2010;11-17.

42. Zack. Chemistry and Structure of Anabolic and Androgenic Steroids. Muscle Talk, UK. 2015.

43. National Geographic Documentary: Anabolic Steroids Effect. National Geographic Wild. 2015.

44. Corticosteroids. NHS, UK. 2015.

45. Ben Johnson at the 1982 Commonwealth Games. Rantsports, UK. 2014.

46. Rashid H, Ormerod S, Day E. Anabolic androgenic steroids: what the psychiatrist needs to know. Advances in Psychiatric Treatment. 200713(3):203-211.

47. Sjöqvist F, Garle M, Rane A. Use of doping agents, particularly anabolic steroids, in sports and society. Lancet. 2008;371(9627):1872-1882.

48. Smith R. Lance Armstrong was both a fraud and cycling's most high profile drugs victim. The Guardian. Talk to frank (2015) Anabolic Steroids. 2014.

49. Schwartz-Bloom R. How Performance Enhancers Work. 2005.

50. Steroids and Women. Steroid.com. 2015.

51. Smith L, Mitchell R, McEwan I. Testosterone. Springer, London, UK $2013 ; 1-2$.

52. Steroid Stacking. Steroid.com. 2015.

53. Anabolic Steroids. Frank. 2015.

54. Looking back on the Ben Johnson scandal, 25years later. TSN. 2013.

55. Ben Johnson: I was nailed on a cross for taking steroids at Seoul Olympics - 25years later I'm still being punished. Telegraph Sport. 2013.

56. Taylor W. Anabolic steroids and the athlete. In: Jefferson NC, McFarland. 2002;374 p.

57. The Lance Armstrong Story-Stop at Nothing. BBC. 2014.

58. Johnson to front anti-drugs campaign. What A Dope ... Ben Johnson in 1988. The sun. 1988.

59. Athlete Jones stripped of Olympic medals. USA. The Guardian. 2007.

60. Marion Jones wins the Women's $100 \mathrm{~m}$ at the Sydney Olympics. USA. Theage. 2004.

61. Walsh D. Seven deadly sins: My Pursuit of Lance Armstrong. 1st ed. Atria Books, New York, USA. 2013.

62. Waddington I, Smith A. An introduction to drugs in sport. Routledge, London, UK. 2009;29 p.

63. Turnbull S. How last Oprah confession by Marion Jones hit a bum note. Independent. 2013.

64. World Anti-Doping Agency (WADA). The Code. USA. 2013. 